Dunja Meštrović

University of Rijeka

51000 Rijeka, Croatia

dmestrovic@uniri.hr

Lidija Bagarić

University of Rijeka

Faculty of Tourism and

Hospitality Management

51000 Rijeka, Croatia

lidijab@fthm.hr
Dina Lončarić

University of Rijeka

Faculty of Tourism and

Hospitality Management

51000 Rijeka, Croatia

dinal@fthm.hr
JEL: C51, I23, M31, Q01

Original scientific paper

https://doi.org/10.51680/ev.34.2.12

Received: April 22, 2021

Revision received: July 26, 2021

Accepted for publishing: July 28, 2021

\title{
ATTITUDES AND PERCEPTIONS OF SUSTAINABLE MARKETING IN HIGHER EDUCATION - DESIGNING A MEASUREMENT INSTRUMENT
}

\section{Abstract}

Purpose: The purpose of this paper is to demonstrate the process of designing the measurement instrument that captures attitudes and perceptions of manifest forms of sustainable marketing in higher education in order to gain an insight into the way of how each selected group of higher education stakeholders perceive and understand the concept and the meaning of sustainable marketing.

Methodology: In order to gain new knowledge, primary research was conducted on a purposive sampling of experts, where 104 valid and complete answers from selected stakeholders related to higher education were received. Quantitative analysis of the collected data was then applied, using descriptive statistics methods and procedures for determining the instrument's dimensionality, validity and reliability.

Results: After the exploratory factor analysis, the multidimensional structure of the proposed measurement instrument of sustainable marketing in higher education was determined, which meets all the given scale validity criteria.

Conclusion: This research has formed a valid measurement instrument of sustainable marketing in higher education of statistical and theoretical significance, which can be used for further research, development and validation.

Keywords: Sustainable marketing, higher education, measurement instrument, scale development

\section{Introduction}

Sustainability has become a movement that is gaining more and more influence in recent times, so sustainable development became a mandatory paradigm today. The concept of sustainable marketing evolved from the concept of green marketing and the economy of sustainable development. Sustainable marketing implies balancing that includes integrated economic, environmental and social goals.
It is therefore considered as a broad management concept that satisfies multiple stakeholders simultaneously. Higher education institutions (HEIs) have great potential for the development and application of sustainable marketing as a prerequisite for creating and enhancing their competitiveness, while achieving three goals: economic, environmental and social. Sustainable marketing is both a macro and a micro concept whose initial elements 
include the analysis of consumer behaviour and current socio-environmental problems in general. The main stakeholders of HEIs are not only students as customers, but also faculties, employers, society, government and the local community. The fundamental role of HEIs is to produce knowledge and innovations and to contribute to the social, economic and environmental challenges (Stephens et al., 2008). By providing the necessary knowledge and incorporating the environmental approach HEIs contribute to the development of stakeholders' capacities and skills for the successful implementation of environmental strategies (Papadas et al., 2017). Regarding the role of higher education, there is still confusion about what exactly sustainable development means, what sustainable development should look like and how to bring a change in organizational culture (Adams et al., 2018; Velazquez et al., 2006).

Since the empirical research on sustainable marketing is limited (Press et al., 2011) and a scarce body of scientific literature focusing on sustainable marketing in higher education sector is published, proposing no applicable measurement scales, this research was applied to fill this gap. There is a need for developing a measurement instrument that captures attitudes and perceptions of manifest forms of sustainable marketing in higher education to examine an insight into how each selected group of higher education stakeholders perceive and understand the concept and the meaning of sustainable marketing. Hence the research problem of this paper is how to properly define a measurement instrument for quantitative research on sustainable marketing in HEIs. It seeks to gain an insight into how members of selected HEI's stakeholder groups view and understand the areas of sustainability and sustainable marketing in higher education.

In order to determine the attitudes and perceptions of key stakeholders on sustainable marketing and its application on HEIs, we started developing and testing a measuring instrument for comprehensive quantitative research that could provide conclusions on the perception and application of sustainable marketing at the University of Rijeka.

This paper is structured as follows: after the introduction, the theoretical and conceptual background discussing sustainability, sustainable marketing and sustainable marketing in HEIs introduces the empirical part of the paper, which describes the process of developing the proposed measurement instrument, sampling and data collection, and instrument's purification and validation. Lastly, we present the obtained results and finalise with the conclusion pointing out the objectives achieved, the research limitations and suggestions for further research.

\section{Theoretical and conceptual background}

Researchers have demonstrated an interest in the field of sustainability in higher education (Mitra, 2009; Nicolescu, 2009; Camino \& Ayala, 2010; Ma \& Todorovic, 2011; Warwick, 2016) and in marketing concepts such as social, economic, environmental and sustainability marketing (Stephens et al., 2008; Abou-Warda, 2014; Shiel et al., 2016; Adams et al., 2018).

\subsection{Sustainability and sustainable marketing}

Sustainability has been recognized as one of the major issues in marketing strategy (Hoffman, 2002; Annamalai et al., 2018), as well as a key factor of innovation (Edwards, 2005; Dangelico \& Vocalelli, 2017), and a relevant topic affecting organizational market performance and stakeholders' involvement (Reilly \& Hynan, 2014). Bridges and Wilhelm (2008) defined sustainable marketing as a holistic, integrative approach that involves economic, social and environmental aspects when developing marketing strategies. Thus, sustainability encompasses marketing approaches: economic (Camino, 2007; Closs et al., 2011; Leal Filho et al., 2019), social (Link, 2007), environmental (Bacow \& Moomaw, 2007; Hawken et al., 2000; Thompson \& Creighton, 2007; Chard et al., 2013; Annamalai et al., 2018), and sustainability marketing (Nidumolu et al., 2009; Chabowski et al., 2011; Abou-Warda, 2014). Some authors argue that companies must have the ability to take the necessary actions to create new ways of producing goods and services that will provide a higher quality of life by minimizing both the use of natural resources and their environmental impact (Almeida, 2002; Montenegro de Lima et al., 2020).

Marketing is focused on meeting consumer's desires and needs (Soares et al., 2019), it represents a social activity, an organizational role and a process for creating, communicating, and adding value to stakeholders for the benefit of all (Keefe, 2004; Kuo \& Smith, 2018). Some studies point to the lack of dialog with stakeholders and their inclusion in decision-making processes and emphasise the necessity 
to develop and establish an integrative approach (Lozano et al., 2013; Leal Filho et al., 2019) to overcome this gap. Thus, there is a need to act integrative when considering the strategic dimensions of sustainability (Disterheft et al., 2013; Berchin et al., 2017). Marketing actions are also needed for the internal organization which is essential for the successful implementation of marketing activities (Sarquis et al., 2020).

\subsection{Sustainable marketing in Higher Education Institutions (HEIs)}

Universities worldwide face a major challenge in responding to rapid changes in the market environment (Ma \& Todorovic, 2011; Aleixo et al., 2018). These changes have pressured HEIs to adopt market-oriented initiatives (Mitra, 2009). Looking back at the not-so-distant past, many HEIs considered sustainability as an unnecessary additional cost (Hawken et al., 2000; Hoffman \& Henn, 2008), but nowadays, HEIs show strong support and commitment to sustainability that has been implemented in their ethical and responsible mission, goals and other activities (Guerra et al., 2018; Lima et al., 2020). In order to achieve sustainability goals, HEIs need to define strategic actions to achieve sustainability and a measurement framework for institutional success during the implementation process (Casarejos et al., 2017; Finnveden et al., 2020). HEIs' managers need to explore and develop a range of sustainable strategies to provide knowledge that can help address contemporary sustainability challenges and raise environmental awareness (Thomashow, 2014). It is interesting to note that legislative requirements are consolidated when HEIs get involved in the issue of environmental sustainability and when they support legal norms and raise community awareness (Grubba et al., 2017). Some authors recommend that HEIs should be more actively involved in the dialogue with internal and external stakeholders, regarding the institutional sustainability achievement (Soares et al., 2019), and environmental responsibility expectations ( $\mathrm{Za}$ hid et al., 2018). The commitment of HEIs to sustainable development can be shown through their participation and engagement in social progress around the world. HEIs present themselves as leading authorities in building a world aimed at this goal (Fuchs et al., 2020).

HEIs should be a key actor in promoting sustainable development, having the opportunity to educate the future leaders and actively participate in facing a number of challenges (Xiong et al., 2013; Beynaghi et al., 2016). The products specifically related to HEIs are their educational services, research projects, courses, and other programs (Sarquis et al., 2020). HEIs can have a great impact on promoting sustainability by paying special attention to encouraging students to adopt sustainable practices and to become more environmentally concerned and friendly (Steiner \& Posch 2005; Merkel \& Litten 2007; Beynaghi et al., 2016). It also has a direct impact on local communities since HEIs are responsible for the creation and flow of scientific knowledge and other important information (Sachs, 2008; Fuchs et al., 2020). Investing in research and education to contribute to the development of a better educated society is one of the main objectives of HEIs (Gholami et al., 2015; Yuan et al., 2013; Guerra et al., 2018).

\section{Methodology}

This section of the paper describes the process of designing the "Sustainable marketing in higher education" (SMHE) measurement instrument, which was supposed to be developed to capture the attitudes and perceptions of HEIs' stakeholders' towards manifest forms of sustainable marketing in higher education.

\subsection{Developing the SMHE measurement instrument}

Consistent with Bearden's and Netemeyer's (1999) considerations for marketing research measurement instrument creation, development and evaluation, the root framework for items aggregation was established by constructs' theoretical outlines and descriptions, as an imperative to adequately capture their theoretical domains. The initial set of items that was generated by adapting existing and creating new items based on prior theoretical and empirical research subject to sustainable higher education, education for sustainable development, and sustainable marketing (Abou-Warda, 2014; Ajzen, 1991, 2002; American Management Association, 2007; Ferdous, 2010; Gaebel et al., 2018; Hillman \& Keim, 2001; Jamrozy, 2007; Jaworski \& Kohli, 1996; Little, 2006; Mrnjaus, 2008; Rončević \& Rafajac, 2012; Rončević et al., 2008; Sidiropoulos \& Sibley, 2013; Siu Noel \& Wilson, 1999; Stern et al., 1995; United Nations' General Assembly, 2015), was pre-checked by five marketing academics following the suggestions for scale development pro- 
cedures (Lewis et al., 2005; DeVellis, 2003; Gerbing \& Anderson, 1988) to confirm the initial pool of items implicate all essential and relevant components subject to sustainable marketing in higher education, thus confirming the measurement instrument's content validity. Subsequently, a convenient sample of 20 students was engaged for pilot testing and items refinement according to Hill (1998) and Bearden \& Netemeyer (1999) to check the items' adequacy and for measurement instrument's improvement and purification.

Following the precursory section with demographic variables, the questionnaire administered respondents' attitudes towards higher education activities contributing to sustainable development, personal beliefs, attitudes and norms towards sustainable marketing in higher education and the potential benefits of its implementation. Respondents were asked to express the level of their accordance with the proposed 48 items administering the subjects' research interest, by selecting corresponding offered values on the Likert-type scale, ranging from 1 (completely disagree) to 7 (completely agree).

\subsection{Sampling and data collection}

Given the lack of precedent research with respect to sustainable marketing in higher education, in order to obtain new insights, primary research was conducted on a purposive sampling of experts according to the recommendation of Kumar et al. (2013). During the last three weeks of April 2019, data was collected using an anonymous, structured self-administered online questionnaire using Google Docs Forms, distributed by e-mail to the total number of 225 stakeholders (university employees, students, local government and other private and public business entities).

After two reminders, a total of 118 responses were collected, 14 unusable or incomplete ones were excluded, so that the response rate was $46.22 \%$ and the analyses were conducted on the responses of 104 questionnaires. From the total number, $64.42 \%$

(67) were female respondents whose mean age was 42 years and 37 (35.58\%) were male, whose mean age was 44 years. 22 respondents $(21.15 \%)$ have the highest level of university education i.e. university postgraduate doctoral or postgraduate specialist degree or equivalent, more than half of the total number of respondents (63 or $60.58 \%$ ) have a university degree equivalent to a master's degree or equivalent and 19 (18.27\%) have a lower level of education (i.e. bachelor's degree or high school).

Since there is no consensus on the sample size adequacy for factor analyses, authors' recommendations range from 50 (de Winter et al., 2009) for statistically significant results for a small number of factors with high factor loadings, up to 500 respondents (Comerey \& Lee, 1992, as cited in MacCallum et al., 1996). According to Hair et al. (2010), who recommend a minimum adequate sample size of 100 , it was concluded that this condition has been met.

\subsection{Measurement instrument purification and valida- tion}

The main objective of this stage of the measurement instrument development process was to refine the initial pool of items and to divert them according to the content review in order to create a valid measurement instrument of sustainable marketing in higher education to be used for further research. Consequently, 48 questionnaire items measured on a 7-point Likert-type scale, with codes ranging from SM2 to SM49 were included in the further analysis as theoretically and conceptually determined and suitable to the subject of the authors' research focus. The proposed instrument's psychometric characteristics were thus evaluated and its internal consistency and scale reliability were analysed.

To examine the construct validity and reduce the initial number of items and to test the underlying dimensions of the construct, using Statistical Package for Social Sciences (SPSS 23.0), the Exploratory Factor Analysis (EFA) using Principal Components Analysis (PCA) with Varimax rotation was conducted as the most suitable since there was no intercorrelation found among the items (Hair et al., 2010). EFA was applied as a convenient method according to Mejovšek (2013) to classify the manifest variables of the construct, aiming to determine its fundamental factors since the factor structure was not already known from previous studies.

The EFA involved initial reliability tests using item communalities with a cutting point value of 0.5 and Kaiser-Meyer-Olkin Measure (KMO) greater than 0.6 to test the suitability of the data for structure detection (Hair et al., 2010). The results of the EFA demonstrate a high KMO value of 0.794 with Bartlett's Test of Sphericity statistically significant $(\chi 2=7189.40$ at $\mathrm{p}<0.01)$, indicating the suitability of the data for 
structure detection, since they were not unrelated. The Cronbach's alpha value for the initial 48-item measurement instrument was 0.822 , which is above the recommended minimum of 0.7 (Hair et al., 2010), demonstrating good reliability (DeVellis, 2003).

In the process of EFA authors indicated $25 \%$ of items as unreliable, since having communalities extracted (CE) values below the acceptable value of 0.4 , factor loadings below 0.5 , factor loadings above 0.3 on more than one factor and loading the "wrong" factor (Hair et al., 2010), i.e. items SM2, SM6, SM7, SM9, SM12, SM13, SM14, SM15, SM36, SM37, SM40 and SM41. Accordingly, the final 36item SMHE measurement instrument was found to be convenient for further study.

Table 1 Exploratory factor analysis of SMHE measurement instrument

\begin{tabular}{|c|c|c|c|c|c|}
\hline \multicolumn{2}{|c|}{ Communalities } & \multicolumn{4}{|c|}{ Rotated Factor Matrix ${ }^{a}$} \\
\hline Item & Initial & Item & 1 & 2 & 3 \\
\hline SM3 & 0.669 & SM3 & 0.589 & 0.026 & -0.098 \\
\hline SM4 & 0.762 & SM4 & 0.681 & 0.011 & 0.117 \\
\hline SM5 & 0.792 & SM5 & 0.625 & 0.212 & 0.264 \\
\hline SM8 & 0.506 & SM8 & 0.518 & 0.120 & 0.290 \\
\hline SM10 & 0.862 & SM10 & 0.571 & 0.231 & 0.141 \\
\hline SM11 & 0.793 & SM11 & 0.547 & 0.194 & 0.248 \\
\hline SM16 & 0.830 & SM16 & 0.122 & 0.606 & 0.234 \\
\hline SM17 & 0.891 & SM17 & -0.216 & 0.718 & 0.132 \\
\hline SM18 & 0.784 & SM18 & 0.191 & 0.727 & 0.111 \\
\hline SM19 & 0.749 & SM19 & -0.015 & 0.624 & 0.269 \\
\hline SM20 & 0.878 & SM20 & 0.051 & 0.784 & 0.184 \\
\hline SM21 & 0.910 & SM21 & 0.122 & 0.796 & 0.298 \\
\hline SM22 & 0.836 & SM22 & 0.232 & 0.740 & 0.125 \\
\hline SM23 & 0.844 & SM23 & 0.154 & 0.741 & 0.256 \\
\hline SM24 & 0.886 & SM24 & 0.139 & 0.784 & 0.168 \\
\hline SM25 & 0.906 & SM25 & 0.231 & 0.761 & 0.215 \\
\hline SM26 & 0.934 & SM26 & 0.145 & 0.730 & 0.272 \\
\hline SM27 & 0.889 & SM27 & 0.236 & 0.710 & 0.123 \\
\hline SM28 & 0.899 & SM28 & 0.136 & 0.726 & 0.226 \\
\hline SM29 & 0.880 & SM29 & 0.243 & 0.721 & 0.144 \\
\hline SM30 & 0.844 & SM30 & 0.141 & 0.681 & 0.232 \\
\hline SM31 & 0.941 & SM31 & 0.247 & 0.154 & 0.693 \\
\hline SM32 & 0.944 & SM32 & 0.104 & 0.128 & 0.736 \\
\hline SM33 & 0.872 & SM33 & 0.241 & 0.145 & 0.715 \\
\hline SM34 & 0.792 & SM34 & 0.154 & 0.041 & 0.696 \\
\hline SM35 & 0.913 & SM35 & 0.261 & 0.150 & 0.817 \\
\hline SM38 & 0.816 & SM38 & 0.236 & -0.065 & 0.591 \\
\hline SM39 & 0.912 & SM39 & 0.134 & 0.021 & 0.788 \\
\hline SM42 & 0.943 & SM42 & 0.245 & 0.103 & 0.747 \\
\hline SM43 & 0.940 & SM43 & 0.125 & 0.189 & 0.737 \\
\hline SM44 & 0.943 & SM44 & 0.293 & 0.241 & 0.815 \\
\hline SM45 & 0.861 & SM45 & 0.271 & 0.229 & 0.823 \\
\hline SM46 & 0.919 & SM46 & 0.293 & 0.201 & 0.823 \\
\hline SM47 & 0.891 & SM47 & 0.222 & 0.135 & 0.773 \\
\hline SM48 & 0.885 & SM48 & 0.235 & 0.186 & 0.738 \\
\hline SM49 & 0.836 & SM49 & 0.295 & 0.249 & 0.645 \\
\hline
\end{tabular}

Source: Authors' calculations 
Following analyses of 36-items data suitability demonstrate a high KMO value of 0.897 with the Bartlett's Test of Sphericity statistically significant $\left(\chi^{2}=4403.61\right.$ at $\mathrm{p}<0.01)$. Although the results demonstrate the instrument at a nascent stage, the three-factor statistically and theoretically acceptable solution was generated after 8 iterations, with Eigenvalues greater than 1 and the total variance explained of $65.35 \%$ (with factor 1 loading $37.23 \%$ variance explained, factor $219.17 \%$ and factor 3 explaining $8.93 \%$ of total variance). A high total scale's Cronbach's alpha of 0.894 , with subscale values ranging from 0.796 to 0.979 which are acceptable for further analysis (Hair et al., 2010), demonstrate the reliability and content validity of the proposed SMHE measurement instrument, as shown in Table 2.

\section{Table 2 SMHE measurement instrument's reliability analysis}

\begin{tabular}{|c|c|c|c|c|}
\hline Item & Construct/Measure & $\begin{array}{l}\text { Cronbach's } \\
\text { alpha }\end{array}$ & $\begin{array}{c}\text { Cronbach's alpha if } \\
\text { item deleted }\end{array}$ & $\begin{array}{l}\text { Item-to-total } \\
\text { correlation }\end{array}$ \\
\hline \multicolumn{2}{|c|}{ Promotion and education for sustainable development (PESD) } & \multicolumn{3}{|l|}{0.859} \\
\hline SM3 & Improving the entire higher education system's quality & & 0.856 & 0.541 \\
\hline SM4 & $\begin{array}{l}\text { Improving continuous professional development and } \\
\text { training of all employees engaged in the higher educa- } \\
\text { tion system }\end{array}$ & & 0.847 & 0.546 \\
\hline SM5 & $\begin{array}{l}\text { Implementation of mutual elective courses on sustain- } \\
\text { able development }\end{array}$ & & 0.834 & 0.645 \\
\hline SM8 & $\begin{array}{l}\text { Implementation of study programs on sustainable de- } \\
\text { velopment }\end{array}$ & & 0.856 & 0.751 \\
\hline SM10 & $\begin{array}{l}\text { Promotion of sustainable development principles } \\
\text { through own business practices }\end{array}$ & & 0.835 & 0.868 \\
\hline SM11 & $\begin{array}{l}\text { Reporting about own endeavours and achievements in } \\
\text { accordance to sustainable development }\end{array}$ & & 0.838 & 0.680 \\
\hline \multicolumn{2}{|c|}{ Sustainable marketing activities (SMA) } & \multicolumn{3}{|l|}{0.979} \\
\hline SM16 & $\begin{array}{l}\text { Promotion of new ideas that contribute to acceptance } \\
\text { and implementation of sustainability as a lifestyle and } \\
\text { business philosophy }\end{array}$ & & 0.978 & 0.773 \\
\hline SM17 & $\begin{array}{l}\text { Concern about environmental and societal long-term } \\
\text { benefits while striving to achieve own business goals }\end{array}$ & & 0.961 & 0.600 \\
\hline SM18 & Partnership with regional and local government bodies & & 0.906 & 0.502 \\
\hline SM19 & Partnership with competitors & & 0.979 & 0.630 \\
\hline SM20 & Partnership with economic entities & & 0.977 & 0.599 \\
\hline SM21 & Partnership with the local community & & 0.978 & 0.709 \\
\hline SM22 & $\begin{array}{l}\text { Adjusting business processes to laws and legal regula- } \\
\text { tions while striving to achieve own business goals }\end{array}$ & & 0.863 & 0.644 \\
\hline SM23 & $\begin{array}{l}\text { Concern about all employees while striving to achieve } \\
\text { own business goals }\end{array}$ & & 0.797 & 0.645 \\
\hline SM24 & $\begin{array}{l}\text { Dialogue with key stakeholders (employers, students, } \\
\text { prospective students, parents of students, employees, } \\
\text { higher education institutions, scientific institutions, rel- } \\
\text { evant ministries, local and regional government bodies } \\
\text { and society at large) }\end{array}$ & & 0.844 & 0.763 \\
\hline SM25 & $\begin{array}{l}\text { Anticipating and respecting the needs of broader com- } \\
\text { munity and future generations }\end{array}$ & & 0.792 & 0.704 \\
\hline
\end{tabular}




\begin{tabular}{|c|c|c|c|c|}
\hline Item & Construct/Measure & $\begin{array}{l}\text { Cronbach's } \\
\text { alpha }\end{array}$ & $\begin{array}{c}\text { Cronbach's alpha if } \\
\text { item deleted }\end{array}$ & $\begin{array}{l}\text { Item-to-total } \\
\text { correlation }\end{array}$ \\
\hline SM26 & $\begin{array}{l}\text { Regularly considering the impacts of own business deci- } \\
\text { sions on various members of stakeholders (employers, } \\
\text { students, potential students, parents of students, em- } \\
\text { ployees, higher education institutions, scientific institu- } \\
\text { tions, relevant ministry, local and regional government } \\
\text { bodies), on natural and financial resources and society } \\
\text { at large }\end{array}$ & & 0.856 & 0.625 \\
\hline SM27 & $\begin{array}{l}\text { Increasing the application of modern information and } \\
\text { communication technology (ICT) in business processes } \\
\text { and teaching methods }\end{array}$ & & 0.725 & 0.794 \\
\hline SM28 & $\begin{array}{l}\text { Increasing the availability of formal, informal and non- } \\
\text { formal education to all stakeholders }\end{array}$ & & 0.888 & 0.774 \\
\hline SM29 & $\begin{array}{l}\text { Transparency and availability of data on own activi- } \\
\text { ties taken that contribute to the society at large and on } \\
\text { efforts being taken to reduce the negative impact on the } \\
\text { environment }\end{array}$ & & 0.978 & 0.853 \\
\hline SM30 & $\begin{array}{l}\text { Acceptance, implementation and application of the } \\
\text { principles of sustainable development as an essential } \\
\text { part of business culture, at all levels and all aspects of } \\
\text { business }\end{array}$ & & 0.978 & 0.720 \\
\hline \multicolumn{2}{|c|}{ Implementation benefits (IB) } & \multicolumn{3}{|l|}{0.796} \\
\hline SM31 & Rationalising usage of resources & & 0.791 & 0.778 \\
\hline SM32 & Increasing efficiency & & 0.744 & 0.790 \\
\hline SM33 & $\begin{array}{l}\text { Creating added value for users while taking into account } \\
\text { long-term interests of both society and environment }\end{array}$ & & 0.719 & 0.788 \\
\hline SM34 & Creating and achieving competitive advantage & & 0.754 & 0.800 \\
\hline SM35 & Improving business performance & & 0.739 & 0.815 \\
\hline SM38 & Increasing study success & & 0.795 & 0.755 \\
\hline SM39 & Increasing the visibility of higher education institution & & 0.794 & 0.743 \\
\hline SM42 & $\begin{array}{l}\text { Intensifying internal and external mobility of students } \\
\text { and employees }\end{array}$ & & 0.701 & 0.742 \\
\hline SM43 & $\begin{array}{l}\text { Simultaneous achievement of environmental, societal } \\
\text { and economic goals }\end{array}$ & & 0.764 & 0.774 \\
\hline SM44 & $\begin{array}{l}\text { Promoting new ideas about sustainability as a new para- } \\
\text { digm and as a lifestyle that leads to sustainable develop- } \\
\text { ment of entire society }\end{array}$ & & 0.753 & 0.736 \\
\hline SM45 & $\begin{array}{l}\text { Creating the change we want to testify as a society at } \\
\text { large }\end{array}$ & & 0.725 & 0.654 \\
\hline SM46 & $\begin{array}{l}\text { Increasing ethics and morality, availability and transpar- } \\
\text { ency of business, procurement and donation data }\end{array}$ & & 0.709 & 0.750 \\
\hline SM47 & Education for sustainable development & & 0.720 & 0.758 \\
\hline SM48 & $\begin{array}{l}\text { Increasing loyalty and satisfaction of users and other } \\
\text { stakeholders }\end{array}$ & & 0.765 & 0.676 \\
\hline SM49 & $\begin{array}{l}\text { Adapting existing and/or creating new study pro- } \\
\text { grammes }\end{array}$ & & 0.790 & 0.661 \\
\hline
\end{tabular}

Source: Authors' calculations 


\section{Results}

The EFA of the statistically significant and theoretically convenient set of 36 items determined three factors of the SMHE construct, named according to the attributable items and the area of interest they operationalise. Since all factors have more than 3 attributable items needed to give it a meaningful interpretation (Henson \& Roberts, 2006), the authors named them at this stage of the inductive, theoretical, and subjective process (Pett et al., 2003) as follows.

The first factor generated which included 6 items considering the topic of educational and encouraging activities contributing to sustainable development was named "Promotion and education for sustainable development - PESD" (Cronbach's Alpha 0.859). The second factor containing 15 items capturing manifest forms of sustainable marketing activities and practices in higher education was named "Sustainable marketing activities - SMA" (Cronbach's Alpha 0.979) and lastly, the third factor determined by 15 items that accessed personal beliefs, attitudes and norms about potential advantages, contributions and benefits of sustainable marketing practices in higher education was named "Implementation benefits - IB" (Cronbach's Alpha 0.796).

\section{Conclusion}

The aim of this paper was to design a measurement instrument that captures attitudes and perceptions of manifest forms towards sustainable marketing in higher education in order to gain insight into higher education stakeholders' understanding and perceptions of the concept and meaning of sustainable marketing. The measurement instrument's content validity, dimensionality and reliability was confirmed and after the exploratory factor analysis, the multidimensional structure of the proposed measurement instrument of sustainable marketing in higher education was determined. The resulting three-dimensional scale encompasses promotion and education for sustainable development, sustainable marketing activities and implementation benefits, which meets all the given scale validity criteria. Due to the lack of prior research studies on sustainable marketing in higher education that outlined the fundamental purpose of this exploratory research, the results obtained could not be accordingly compared but can serve as a starting point for further studies in the same scope of the research topic. While this research has formed a valid measurement instrument of sustainable marketing in higher education of statistical and theoretical significance, the authors, aware of its limitations that may have impacted the results and conclusions, suggest the proposed measurement instrument to be employed to a larger sample size that includes a wider range of population profiles for further research, measurement instrument's improvement, development and validation. 


\section{REFERENCES}

1. Abou-Warda, S. H. (2014). A synthesis model of sustainable market orientation: conceptualization, measurement, and influence on academic accreditation - a case study of Egyptian-accredited faculties. Journal of Marketing for Higher Education, 24, 196-221.

https://doi.org/10.1080/08841241.2014.909555

2. Adams, R., Martin, S. \& Boom, K. (2018). University culture and sustainability: Designing and implementing an enabling framework. Journal of Cleaner Production, 171, 434-445.

https://doi.org/10.1016/j.jclepro.2017.10.032

3. Ajzen, I. (1991). The theory of planned behavior: Organizational behavior and human decision processes. Journal of Fundamental Research and Theory in Applied Psychology, 50(2), 179-211. https://doi.org/10.1016/0749-5978(91)90020-T

4. Ajzen, I. (2002). Perceived Behavioral Control, Self-Efficacy, Locus of Control, and the Theory of Planned Behavior. Journal of Applied Social Psychology, 32, 665-683. https://doi.org/10.1111/j.1559-1816.2002.tb00236.x

5. Aleixo, A. M., Azeiteiro, U. \& Leal, S. (2018). The implementation of sustainability practices in Portuguese higher education institutions. International Journal of Sustainability in Higher Education, 19(1), 146-178. https://doi.org/10.1108/IJSHE-02-2017-0016

6. Almeida, F. (2002). O Bom Negócio da Sustentabilidade. Nova Fronteira.

7. American Management Association (2007). Creating a sustainable future: A global study of current trends and possibilities. AMA.

8. Annamalai, S., Kumar, K. R., Jothikumar, R. \& Hung, Y.T. (2018). Environmental sustainability of green marketing strategy: empirical evidence from e-tail consumer's in Tamil Nadu. International Journal of Environment and Waste Management, 22(1/2/3/4), 215-227. https://doi.org/10.1504/IJEWM.2018.094109

9. Bacow, L. \& Moomaw, W. (2007). The university case for sustainability. New Directions for Institutional Research. Special Issue: Advancing Sustainability in Higher Education, 2007(134), 37-40. https://doi.org/10.1002/ir.211

10. Bearden, W. O. \& Netemeyer, R. G. (1999). Handbook of marketing scales: Multi-item measures for marketing and consumer behavior research. Sage Publications. https://doi.org/10.4135/9781452224923

11. Berchin, I. I., Grando, V. S., Marcon, G. A., Corseuil, L. \& Guerra, J. B. S. O. A. (2017). Strategies to promote sustainability in higher education institutions: a case study of a federal institute of higher education in Brazil. International Journal of Sustainability in Higher Education, 18(7), 1018-1038. https://doi.org/10.1108/IJSHE-06-2016-0102

12. Beynaghi, A., Trencher, G., Moztarzadeh, F., Mozafari, M., Maknoon, R. \& Leal Filho, W. (2016). Future sustainability scenarios for universities: Moving beyond the united nations decade of education for sustainable development. Journal of Cleaner Production, 112, 3464-3478.

https://doi.org/10.1016/j.jclepro.2015.10.117

13. Bridges, C. M. \& Wilhelm, W. B. (2008). Going beyond green: The why and how of integrating sustainability into the marketing curriculum. Journal of Marketing Education, 30(1), 33-46.

https://doi.org/10.1177/0273475307312196

14. Camino, J. R. (2007). Re-evaluating green marketing strategy: A stakeholder perspective. European Journal of Marketing, 41(11/12), 1328-1358. https://doi.org/10.1108/03090560710821206

15. Camino, J. R. \& Ayala, V. M. (2010). Market orientation at universities: Construct and exploratory validation. Innovar, 20(36), 125-136.

16. Casarejos, F., Frota, M. N. \& Gustavson, L. M. (2017). Higher education institutions: a strategy towards sustainability. International Journal of Sustainability in Higher Education, 18(7), 995-1017.

https://doi.org/10.1108/IJSHE-08-2016-0159 
17. Chabowski, B. R., Mena, J. A. \& Gonzalez-Padron, T. L. (2011). The structure of sustainability research in marketing, 1958-2008: A basis for future research opportunities. Journal of the Academy of Marketing Science, 39(1), 55-70. https://doi.org/10.1007/s11747-010-0212-7

18. Chard, C., Cheryl, M. \& Cheri, B. (2013). Marketing and environmental sustainability in the sport sector: Developing a research agenda for action. Journal of Management and Sustainability, 3(1), 33-44. https://doi.org/10.5539/jms.v3n1p45

19. Closs, D. J., Speier, C. \& Meacham, N. (2011). Sustainability to support end-to-end value chains: The role of supply chain management. Journal of the Academy of Marketing Science, 39(1), 101-116. https:// doi.org/10.1007/s11747-010-0207-4

20. Dangelico, R. M. \& Vocalelli, D. (2017). Green marketing: an analysis of definitions, strategy steps, and tools through a systematic review of the literature. Journal of Cleaner Production, 165, 1263-1279. https://doi.org/10.1016/j.jclepro.2017.07.184

21. DeVellis, R. F. (2003). Scale Development: Theory and Applications (2nd ed). Sage Publications.

22. De Winter, J. C. F., Dodou, D. \& Wieringa, P. A. (2009). Exploratory Factor Analysis with Small Sample Sizes. Multivariate Behavioral Research, 44, 147-181. https://doi.org/10.1080/00273170902794206

23. Disterheft, A., Caeiro, S., Azeiteiro, U. M. \& Leal, Filho, W. (2013). Sustainability Science and Education for Sustainable Development in Universities: A Way for Transition. In Caeiro, S. et al. (Eds.), Sustainability Assessment Tools in Higher Education Institutions (pp. 3-27). Springer. https://doi. org/10.1007/978-3-319-02375-5_1

24. Edwards, A. R. (2005). The Sustainability Revolution: Portrait Of A Paradigm Shift. New Society Publishers.

25. Ferdous, A. S. (2010). Applying the Theory of Planned Behavior to Explain Marketing Managers' Perspectives on Sustainable Marketing. Journal of International Consumer Marketing, 22, 313-325. https://doi.org/10.1080/08961530.2010.505883

26. Finnveden, G., Friman, E., Mogren, A., Palmer, H., Sund, P., Carstedt, G., Lundberg, S., Robertsson, B., Rodhe, H. \& Svärd, L. (2020). Evaluation of integration of sustainable development in higher education in Sweden. International Journal of Sustainability in Higher Education, 21(4), 685-698. https://doi.org/10.1108/IJSHE-09-2019-0287

27. Fuchs, P., Raulino, C., Conceição, D., Neiva, S., Amorim, W.S.d., Soares, T. C., Andrade de Lima, M., Montenegro De Lima, C. R., Soares, J. C. \& Andrade Guerra, J. B. S. O. d. A. (2020). Promoting sustainable development in higher education institutions: the use of the balanced scorecard as a strategic management system in support of green marketing. International Journal of Sustainability in Higher Education, 21(7), 1477-1505. https://doi.org/10.1108/IJSHE-02-2020-0079

28. Gaebel, M., Zhang, T., Bunescu, L. \& Stoeber, H. (2018). Learning and teaching in the European higher education area. European University Association.

29. Gerbing, D. W. \& Anderson, J. C. (1988). An updated paradigm for scale development incorporating unidimensionality and its assessment. Journal of Marketing Research, 25(2), 186-192. https://doi.org/10.1177/002224378802500207

30. Gholami, H., Saman, M. Z. M., Sharif, S. \& Zakuan, N. (2015). A CRM strategic leadership towards sustainable development in student relationship management: SD in higher education. Procedia Manufacturing, 2, 51-60. https://doi.org/10.1016/j.promfg.2015.07.010

31. Grubba, L. S., Pellenz, M. \& Bastiani, A. C. B. (2017). Senso humanitario Em detrimento Da seletividade penal: Perspectivas a partir De 'vigiar E punir. Argumenta Journal Law, Jacarezinho - PR, 26, 5980.

32. Guerra, J. B. S. O., Garcia, J., de Andrade Lima, M., Barbosa, S. B., Heerdt, M. L. \& Berchin, I. I. (2018). A proposal of a balanced scorecard for an environmental education program at universities. Journal of Cleaner Production, 172, 1674-1690. https://doi.org/10.1016/j.jclepro.2016.11.179

33. Hair, J. F., Black, W. C., Babin, B. J. \& Anderson, R. E. (2010). Multivariate data analysis: Global edition. Pearson Education Limited. 
34. Hawken, P., Lovins, A. \& Lovins, L. H. (2000). Natural Capitalism: Creating the Next Industrial Revolution. Little Brown and Company.

35. Henson, R. K. \& Roberts, J. K. (2006). Use of exploratory factor analysis in published research: Common errors and some comment on improved practice. Educational and Psychological Measurement, 66(3), 393-416. https://doi.org/10.1177/0013164405282485

36. Hill, R. (1998). What sample size is "enough" in internet survey research. Interpersonal Computing and Technology: An Electronic Journal for the 21st Century 6(3-4), 1-12.

37. Hillman, A. J. \& Keim, G. D. (2001). Shareholder value, stakeholder management, and social issues: what's the bottom line? Strategic Management Journal, 22(2), 125-139. https://doi.org/10.1002/1097-0266(200101)22:2\%3C125::AID-SMJ150\%3E3.0.CO;2-H

38. Hoffman, A. J. (2002). From Heresy to Dogma: An Institutional History of Corporate Environmentalism. Expanded Edition. Stanford Business Books.

39. Hoffman, A. J. \& Henn, R. (2008). Overcoming the Social and Psychological Barriers to Green Building. Ross School of Business Working Paper Series, 1106, 1-45.

40. Jamrozy, U. (2007). Marketing of tourism: a paradigm shift toward sustainability. International Journal of Culture, Tourism and Hospitality Research, 1, 117-130. https://doi.org/10.1108/17506180710751669

41. Jaworski, B. J. \& Kohli, A. (1996). Market orientation: Review, refinement, and roadmap. Journal of Market-Focused Management, 1, 119-135. https://doi.org/10.1007/BF00128686

42. Keefe, L. M. (2004). What is the meaning of 'marketing'?. Marketing News, 15, 16-18.

43. Kumar, V., Rahman, Z. \& Kazmi, A. A. (2013). Sustainability marketing strategy: An analysis of recent literature. Global Business Review, 14(4), 601-625. https://doi.org/10.1177/0972150913501598

44. Kuo, T. C. \& Smith, S. (2018). A systematic review of technologies involving eco-innovation for enterprises moving towards sustainability. Journal of Cleaner Production, 192, 207-220.

https://doi.org/10.1016/j.jclepro.2018.04.212

45. Leal Filho, W., Salvia, A. L., do Paço, A., Anholon, R., Quelhas, O. L. G., Rampasso, I. S., Ng, A., Balogun, A. L., Kondev, B. \& Brandli, L. L. (2019). A comparative study of approaches towards energy efficiency and renewable energy use at higher education institutions. Journal of Cleaner Production, 237, 237-210. https://doi.org/10.1016/j.jclepro.2019.117728

46. Lewis, B. R., Templeton, G. F. \& Byrd, T. A. (2005). A methodology for construct development in MIS research. European Journal of Information Systems, 14(4), 388-400.

https://doi.org/10.1057/palgrave.ejis.3000552

47. Lima, M. A., Serra, F. A. R., Soares, T. C. \& Lima, C. R. M. (2020). Strategy or legitimacy? Analysis of the role of institutional development plans in Brazilian universities. Brazilian Business Review, 17(1), 66-96. https://doi.org/10.15728/bbr.2020.17.1.4

48. Link, T. (2007). Social indicators of sustainable progress for higher education. Advancing Sustainability in Higher Education, 2007(134), 71-82. https://doi.org/10.1002/ir.214

49. Little, A. D. (2006). The Innovation High Ground: Winning Tomorrow's Customers Using Sustainability-Driven Innovation. Strategic Direction, 22(1), 35-37. https://doi.org/10.1108/02580540610635942

50. Lozano, R., Lukman, R., Lozano, F. J., Huisingh, D. \& Lambrechts, W. (2013). Declarations for sustainability in higher education: becoming better leaders, through addressing the university system. Journal of Cleaner Production, 48, 10-19. https://doi.org/10.1016/j.jclepro.2011.10.006

51. Ma, J. \& Todorovic, Z. (2011). Making universities relevant: Market orientation as a dynamic capability within institutions of higher education learning. Academy of Marketing Studies Journal, 15(2), 1-15.

52. MacCallum, R. C., Browne, M. W. \& Sugawara, H. M. (1996). Power analysis and determination of sample size for covariance structure modelling. Psychological Methods, 1(2), 130.

https://doi.org/10.1037/1082-989X.1.2.130

53. Mejovšek, M. (2013). Metode znanstvenog istraživanja u društvenim i humanističkim znanostima. Naklada Slap. 
54. Merkel, J. \& Litten, L. H. (2007). The Sustainability Challenge. Advancing Sustainability in Higher Education. New Directions for Institutional Research, 2007(134), 7-26. https://doi.org/10.1002/ir.209

55. Mitra, S. K. (2009). Why universities are adopting market oriented management practices? Asian Social Science, 5(3), 137-142. https://doi.org/10.5539/ass.v5n3p137

56. Montenegro de Lima, C. R., Coelho Soares, T., Andrade de Lima, M., Oliveira Veras, M. \& Andrade Guerra, J. B. S. O. A. (2020). Sustainability funding in higher education: A literature-based review. International Journal of Sustainability in Higher Education, 21(3), 441-464. https://doi.org/10.1108/IJSHE-07-2019-0229

57. Mrnjaus, K. (2008). Obrazovanje za održivi razvoj. Cjeloživotno učenje za održivi razvoj, 2, 29-34.

58. Nicolescu, L. (2009). Applying marketing to higher education: Scope and limits. Management E Marketing, 4(2), 35-44.

59. Nidumolu, R., Prahalad, C. K. \& Rangaswami, M. R. (2009). Why sustainability is now the key driver of innovation. Harvard Business Review, 87, 56-64.

60. Papadas, K. K., Avlonitis, G. J. \& Carrigan, M. (2017). Green marketing orientation: conceptualization, scale development and validation. Journal of Business Research, 80, 236-246.

https://doi.org/10.1016/j.jbusres.2017.05.024

61. Pett, M. A., Lackey, N. R. \& Sullivan, J. J. (2003). Making sense offactor analysis: The use offactor analysis for instrument development in health care research. Sage. https://doi.org/10.4135/9781412984898

62. Press, M., Arnold, E., Martin, D. \& Schouten, J. (2011). New empirical research on marketing and sustainability. 5th annual international conference on business \& sustainability. Portland State University, Portland.

63. Reilly, A. H. \& Hynan, K. A. (2014). Corporate communication, sustainability, and social media: It's not easy (really) being green. Business Horizons, 57(6), 747-758. https://doi.org/10.1016/j.bushor.2014.07.008

64. Rončević, N., Ledić, J. \& Ćulum, B. (2008). Nisam sigurna što je, ali je bitno - analiza stavova studenata Sveučilišta u Rijeci o održivom razvoju. Suvremene teme: međunarodni časopis za društvene $i$ humanističke znanosti, 1(1), 62-75.

65. Rončević, N. \& Rafajac, B. (2012). Održivi razvoj - izazov za sveučilište. Faculty of Humanities and Social Sciences, University of Rijeka

66. Sachs, I. (2008). Desenvolvimento: includente, sustentável, sustentado. Garamond.

67. Sarquis, A. B., Matos, O. A., Soares, J. C., Borges, G. J. R. \& da Silva Nascimento, A. M. (2020). Internal marketing practices in the educational institution. Revista Gestão Universitária na América Latina Gual, 13(1), 227-250. https://doi.org/10.5007/1983-4535.2020v13n1p227

68. Shiel, C., Leal Filho, W., do Paço, A. \& Brandli, L. (2016). Evaluating the engagement of universities in capacity building for sustainable development in local communities. Evaluation and Program Planning, 54, 123-134. https://doi.org/10.1016/j.evalprogplan.2015.07.006

69. Sidiropoulos, L., Wex, I. \& Sibley, J. (2013). Supporting the sustainability journey of tertiary international students in Australia. Australian Journal of Environmental Education, 29(1), 52-79. https://doi.org/10.1017/aee.2013.15

70. Siu Noel, Y. M. \& Wilson, R. M. S. (1999). Modelling market orientation: An application in the education sector. Journal of Marketing Management, 14(4/5), 296-313. https://doi.org/10.1362/026725798784959453

71. Soares, J., Sarquis, A., Cohen, D. \& Soares, T. C. (2019). Social media marketing communication: effect of interactivity and vividness on user engagement, Revista Brasileira de Marketing, 18(4), 244-268. https://doi.org/10.5585/remark.v18i4.14321

72. Steiner, G. \& Posch, A. (2005). Higher Education for Sustainability by Means of Transdisciplinary Case Studies: An Innovative Approach for Solving Complex, Real-World Problems. Journal of Cleaner Production, 14(911), 877-890. https://doi.org/10.1016/j.jclepro.2005.11.054 
73. Stephens, J. C., Hernandez, M. E., Roman, M., Graham, A. C. \& Scholz, R. W. (2008). Higher education as a change agent for sustainability in different cultures and contexts. International Journal of Sustainability in Higher Education, 9(3), 317-338. https://doi.org/10.1108/14676370810885916

74. Stern, P. C., Kalof, L., Dietz, T. \& Guagnano, G. A. (1995). Values, beliefs, and pro-environmental action: attitude formation toward emergent attitude objects. Journal of Applied Social Psychology, 25(18), 1611-1636. https://doi.org/10.1111/j.1559-1816.1995.tb02636.x

75. Thomashow, M. (2014). The nine elements of a sustainable campus. Sustainability: The Journal of Record, 7(3), 174-175. https://doi.org/10.1089/SUS.2014.9788

76. Thompson, G. \& Creighton, S. H. (2007). Metrics and meaning for environmental sustainability. New Directions for Institutional Research, 2007(134), 41-54. https://doi.org/10.1002/ir.212

77. United Nations' General Assembly (2015). RES/70/1. Transforming our world: the 2030 agenda for sustainable development. https://stg-wedocs.unep.org/bitstream/handle/20.500.11822/11125/unepswiosm1inf7sdg.\%20pdf?sequence $=1$

78. Velazquez, L., Munguia, N., Platt, A. \& Taddei, J. (2006). Sustainable university: what can be the matter? Journal of Cleaner Production, 14, 810-819. https://doi.org/10.1016/j.jclepro.2005.12.008

79. Warwick, P. (2016). An integrated leadership model for leading education for sustainability in higher education and the vital role of students as change agents. Management in Education, 30(3), 105-111. https://doi.org/10.1177/0892020616653463

80. Xiong, H., Fu, D., Duan, C., Chang'E, L., Yang, X. \& Wang, R. (2013). Current status of green curriculum in higher education of mainland China. Journal of Cleaner Production, 61, 100-105. https://doi.org/10.1016/j.jclepro.2013.06.033

81. Yuan, X., Zuo, J. \& Huisingh, D. (2013). Green universities in China - what matters? Journal of Cleaner Production, 61, 36-45. https://doi.org/10.1016/j.jclepro.2012.12.030

82. Zahid, M. M., Ali, B., Ahmad, M. S., Thurasamy, R. \& Amin, N. (2018). Factors affecting purchase intention and social media publicity of green products: the mediating role of concern for consequences. Corporate Social Responsibility and Environmental Management, 25(3), 225-236. https://doi.org/10.1002/csr.1450 
